\title{
Resumed forest grazing restored a population of Euphydryas aurinia (Lepidoptera: Nymphalidae) in SE Finland
}

\author{
KIMmo SAARINEN, JUHA JANTUNEN and ANU VALTONEN \\ South Karelia Allergy and Environment Institute, Lääkäritie 15, FI-55330 Tiuruniemi, Finland; e-mail: all.env@inst.inet.fi
}

Key words. Butterflies, Nymphalidae, Euphydryas aurinia, forest grazing, habitat restoration, moths, Succisa pratensis

\begin{abstract}
In 1996, an old forest pasture grazed from the 1960s to 1988 was restored by coppicing, fencing and grazing by cattle to protect a local population of the endangered butterfly Euphydryas aurinia. An adjoining ungrazed meadow provided a control. In the first years, the butterfly became almost extinct due to the nearly complete consumption of the host plant of the larva, Succisa pratensis, by cattle. The butterfly population quickly recovered when the grazing pressure was lowered. Thus, the intensity of management should be adjusted by continuous monitoring of the target species. In the $2000 \mathrm{~s}$, the annual population was about 50 butterflies, but marked fluctuations took place, probably caused by natural factors. Grazing benefited the meadow flora and improved the habitat of butterflies in general. Extensive forest grazing clearly has the potential for enhancing biodiversity. The value of the experiment is, however, limited because only a single pair of meadows was available for comparison. In the future, it will be even more difficult to arrange a similar experiment due to the great decline in the numbers of traditional meadows and forest grazing in SE Finland.
\end{abstract}

\section{INTRODUCTION}

The marsh fritillary Euphydryas aurinia (Rottemburg, 1775) has suffered a severe decline throughout Europe as a consequence of habitat loss, mainly related to changes in agricultural practices (Warren, 1994; Lewis \& Hurford, 1997; van Swaay \& Warren, 1999). The species is listed as threatened in Annex II of the European Community Habitats and Species Directive. Highly dynamic populations, classified as metapopulations (Wahlberg et al., 2002a; Anthes et al., 2003), occur in marshy, unfertilised meadows with rich colonies of Succisa pratensis (Moench), the exclusive foodplant of its larvae in Britain and northern Europe (van Swaay \& Warren, 1999). Both species commonly rely on the maintenance of traditional low intensity grazing regimes (Adams, 1955; Warren, 1994; Munguira et al., 1997). In Britain, the majority of E. aurinia habitats are grazed by cattle (Lavery, 1993; Barnett \& Warren, 1995).

In Finland, E. aurinia has been protected by law since 1994. It is classified as vulnerable, mostly due to overgrowth and afforestation of semi-natural grasslands, and the cessation of forest grazing (Rassi et al., 2001). Nowadays the range of the species has contracted to the southeastern parts of the country (Huldén et al., 2000), where it inhabits early successional habitats such as forest clearings, open areas under power lines and mesic and fresh meadows along the edges of woodland (Klemetti, 1998; Wahlberg et al., 2002b). Despite the species being rather sedentary, some emigrating individuals tend to move long distances (Warren, 1994; Wahlberg et al., 2002a). The adults are in flight in June, males using both perching and patrolling tactics in search of females to mate, and the females laying batches of on average 270 eggs on the leaves of Succisa (Klemetti \& Wahlberg, 1997; Wahlberg, 2000). The first batch is typically laid in the natal habitat (Wahlberg et al., 2002b). Small larvae feed and overwinter communally in a silk hibernaculum (web), on which they bask in spring after the disappearance of the snow cover. The larvae remain communal until the fifth instar, when they start to disperse.

The distribution of E. aurinia colonies is usually clustered (Lewis \& Hurford, 1997). In Finland, one of the strongest metapopulations occurs in the Joutseno region. In 1996, Klemetti (1998) found 59 occupied habitat patches out of a total of 118 evaluated as suitable for the species. More than half of the local populations (62\%) inhabited clearcut areas, which are the most critical resource for the survival of the species in this area. A clearcut site, however, is suitable for the species for no longer than a decade because of succession, which increases the importance of the remaining meadow habitats (Wahlberg et al., 2002b). Only one extensively grazed meadow site exists in this area. In 1991, a population of E. aurinia was discovered in a forest pasture, where management had ceased three years earlier. In 1996, we restored and re-organised the grazing management in this meadow site.

The main objective was to protect one of the strongest local populations of E. aurinia in Finland by resuming the traditional management of the site. In addition, we evaluated the effects of resumed grazing on the Lepidopteran fauna and diversity of plants by comparing the open pasture to an adjacent ungrazed habitat. The main expectations were: (i) Euphydryas aurinia and Succisa pratensis are favoured by the low intensity grazing, (ii) the extensive forest grazing results in a higher species diversity and total abundance of Lepidoptera, and (iii) the grazing increases the diversity of meadow plants.

\section{MATERIAL AND METHODS}

The forest dominated pasture at Joutseno, SE Finland, was grazed by $3-4$ heifers or two horses from the early 1960 s to the year 1988. The annual grazing period was from early June to 


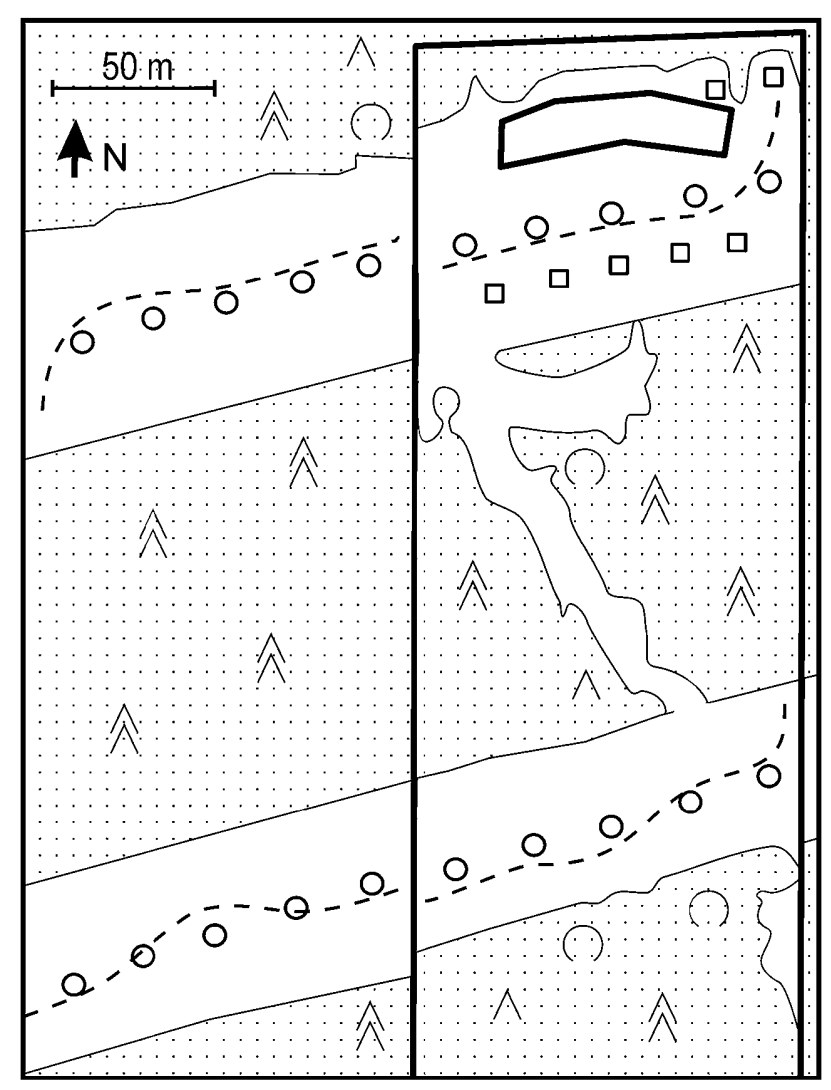

Fig. 1. The northern edge of the restored pasture (fence indicated by the thick line, with a smaller Succisa enclosure) with the two meadows linked by an open corridor in the forest. The dotted line represents the Lepidoptera transects in both the grazed and ungrazed meadow. Open circles $=$ vegetation plots (20) used in the comparison of the grazed and ungrazed meadow. Open squares $=$ vegetation quadrats (7) used in the monitoring of the effects of grazing on the vegetation.

early September. Between 1988 and 1996, natural succession occurred in the absence of grazing. Willows and Filipendula ulmaria, in particular, colonized the two open grasslands in the area. At the same time, Succisa, among other meadow species, decreased.

The site was restored in the spring of 1996. A fence was rebuilt, overgrown meadows were coppiced and an open corridor was logged in the luxuriant forest between the two meadows to enhance the dispersal of E. aurinia. Wooded habitats characterised by Picea and several deciduous species in the tree cover predominate at the restoration site ( $3.8 \mathrm{ha})$, but one third of the area ( $1.3 \mathrm{ha})$ consists of open habitats suitable for $E$. aurinia and Succisa (Fig. 1). Open meadows under power lines extend into the adjacent forests, and provide ungrazed control sites of equal size and edaphic conditions. There was no restoration of the control sites. Soil samples collected at a depth of 15 $\mathrm{cm}$ in the middle of the grazed (3 samples) and ungrazed meadow (3 samples) in August 2003 indicated a rather similar acidity of the soil ( $\mathrm{pH} 5.90$ vs. 5.78), but concentrations of nitrogen ( 1.9 vs. $\left.2.6 \mathrm{~g} \mathrm{~kg}^{-1}\right)$, phosphorus ( 0.6 vs. $0.8 \mathrm{~g} \mathrm{~kg}^{-1}$ ) and potassium (5.6 vs. $6.8 \mathrm{~g} \mathrm{~kg}^{-1}$ ) were slightly higher in the ungrazed controls.

Grazing was restarted in June 1996. In each year, 2-3 heifers have grazed for approximately two months between June and October (Table 1), the duration depending on the availability of food resources, determined by the number of grazers, the pro- portion of the area grazed, and summer rainfall. Between 1997 and 1999, the northern meadow was left ungrazed as it was overgrazed in 1996. During that period the animals were fed by supplementary hay and protein-rich supplements (cereal meal), and provided with mineral licks, in the southern meadow. More recently, a small enclosure ( $0.1 \mathrm{ha})$ has protected the highest density of Succisa in the northern meadow (Fig. 1). Since 2001, heifers have had access to this enclosure for 2 or 3 weeks at the end of the grazing period.

Between 1996 and 2004, the annual population size of E. aurinia was evaluated by counting the number of winter webs and post-diapause larvae in the spring. Grazed meadows and ungrazed controls were thoroughly examined over a period of 2-3 days after the snow melted, usually in late April (Table 1). The numbers of adult E. aurinia and other Lepidoptera were determined using transect counts (Pollard \& Yates, 1993). All individuals within a range of $2.5 \mathrm{~m}$ on both sides and $5 \mathrm{~m}$ in front of the recorder were counted along a standard transect situated in the middle of the clearing beneath the power lines (Fig. 1). The transect was of equal length in the grazed $(250 \mathrm{~m})$ and ungrazed meadow $(250 \mathrm{~m})$. Between 2001 and 2004, 13 weekly censuses were made from early June (week 23) to late August (week 35) each year, resulting in a total of 52 censuses. All counts were made when the weather conditions were satisfactory. Due to the relatively short flight period of E. aurinia, the number of individuals was further determined during the peak flight period in June 2003 (20.6., 25.6.) and 2004 (16.6., 25.6.). These additional counts of E. aurinia adults were made by all three authors during zigzag walks across open areas in both the grazed meadows and control sites.

The total abundance and species richness (i.e. the total number of species recorded in transect counts) of butterflies (Hesperioidea, Papilionoidea) and diurnal moths (Zygaenoidea, Lasiocampoidea, Bombycoidea, Geometroidea, Noctuoidea) on the grazed meadow and ungrazed control site were compared. We used the non-parametric Wilcoxon paired samples test (Siegel, 1956) and the weekly averages of the transect counts; weekly values were preferred due to the annual variation in the timing of the grazing period. Differences in the species composition of the two habitats were tested using a non-parametric multi-response permutation procedure (MRPP) and an Euclidean distance measure (Zimmerman et al., 1985).

The vegetation of grazed meadows was compared to that of ungrazed controls by 20 sample plots $(1 \times 1 \mathrm{~m})$ located systematically along the Lepidopteran transect (Fig. 1). All plots were studied once, on 27 June 2002. In addition, the succession of vegetation in the northern grazed meadow was monitored in seven quadrats $(2 \times 2 \mathrm{~m})$ between 1995 and 2004 . The number of

TABLE 1 . The dates and details of the grazing and data collection over the period between 1996 to 2004 .

\begin{tabular}{ccccccc}
\hline \multirow{2}{*}{ Year } & \multicolumn{2}{c}{ Number of } & & \multicolumn{3}{c}{ Dates of } \\
\cline { 2 - 3 } \cline { 5 - 7 } & heifers & $\begin{array}{c}\text { grazing } \\
\text { days }\end{array}$ & & $\begin{array}{c}\text { grazing } \\
\text { period }\end{array}$ & $\begin{array}{c}\text { vegetation } \\
\text { monitoring }\end{array}$ & $\begin{array}{c}\text { web/larvae } \\
\text { counts }\end{array}$ \\
\hline 1996 & 3 & 55 & & $5.6 .-29.7$. & 26.7. & not available \\
1997 & 2 & 57 & & $15.6 .-10.8$. & 17.7. & not available \\
1998 & 2 & 54 & & $21.6 .-13.8$. & 16.7. & 8.5. \\
1999 & 2 & 85 & & $12.6 .-4.9$. & 2.7. & $18.4 ., 20.4 ., 25.4$. \\
2000 & 3 & 58 & & $10.6 .-6.8$. & 14.7. & $17.4 ., 20.4 ., 25.4$. \\
2001 & 2 & 64 & & $10.6 .-12.8$. & 9.7. & $6.4 ., 10.4$. \\
2002 & 3 & 50 & & $7.6 .-26.7$. & 27.6. & $22.4 ., 30.4$. \\
2003 & 3 & 70 & & $26.6 .-4.9$. & 18.7. & $22.4 ., 25.4$. \\
2004 & 3 & 71 & $23.7 .-2.10$. & 15.7. & $19.4 ., 25.4 ., 30.4$. \\
\hline & & & & &
\end{tabular}




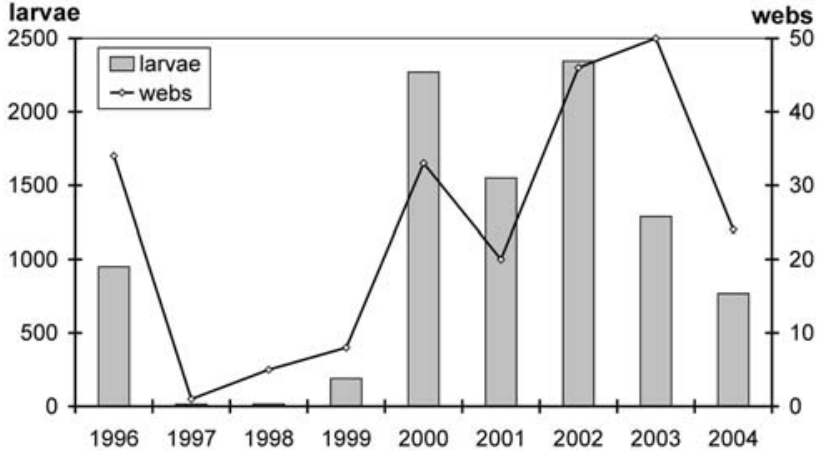

Fig. 2. The annual total numbers of webs and larvae of the Euphydryas aurinia butterfly in the study area, in both the grazed and ungrazed meadow.

vascular plant species in sample plots and quadrats was determined and the coverage $(0-100 \%)$ of each taxon was estimated visually. In order to avoid a bias introduced by annual differences in the growing seasons, the annual monitoring of quadrats was scheduled according to the effective thermal sum (mean 638 , range 543-700), calculated using the formula $\Sigma\left(T_{i}-5^{\circ} \mathrm{C}\right)$, where $T_{i}=$ daily mean temperature $>5^{\circ} \mathrm{C}$. In the grazed meadows and ungrazed control sites, the total number of both fertile and sterile Succisa shoots was counted during the flowering season in August 2004.

\section{RESULTS}

The numbers of both communal webs and larvae of Euphydryas aurinia declined after the grazing was resumed, almost resulting in the extinction of the species at the restoration site in 1997 (Fig. 2). Since then the species has recovered and the present numbers indicate a viable population. In the ungrazed controls the annual numbers of larvae ranged from 13 to 55 in one to four communal webs only, indicating more larvae in the grazed meadows. In 1997, however, three of the four webs detected were located in the ungrazed controls. The greatest number of larvae were located in sites with the highest densities of Succisa shoots (Fig. 3).

Correspondingly, E. aurinia adults preferred grazed meadows, in particular the northern meadow. Of a total 107 individuals recorded in the additional surveys during 2003 and 2004, 95 (89\%) were observed in the grazed habitat. Furthermore, 88 (93\%) of the latter were seen in the northern meadow. Weekly transect counts recorded considerably lower numbers of $E$. aurinia in the same years (29), but again most of the individuals (26; 90\%) were observed in the grazed meadows. Based on the transect counts over the whole study period, the abundance of E. aurinia (94 individuals) was significantly higher in the grazed habitat (Wilcoxon paired samples test, $P=0.046$ ).

The transect counts of Lepidoptera recorded 82 species and 3,302 individuals. Butterflies (42 species, 2,235 individuals) were more abundant than diurnal moths (40 species, 1,067 individuals). The species richness of the two habitats did not differ significantly, but the total abundance was higher in grazed meadows (Table 2). Butterflies preferred grazed meadows, whereas diurnal moths exhibited a slight preference for the ungrazed controls.

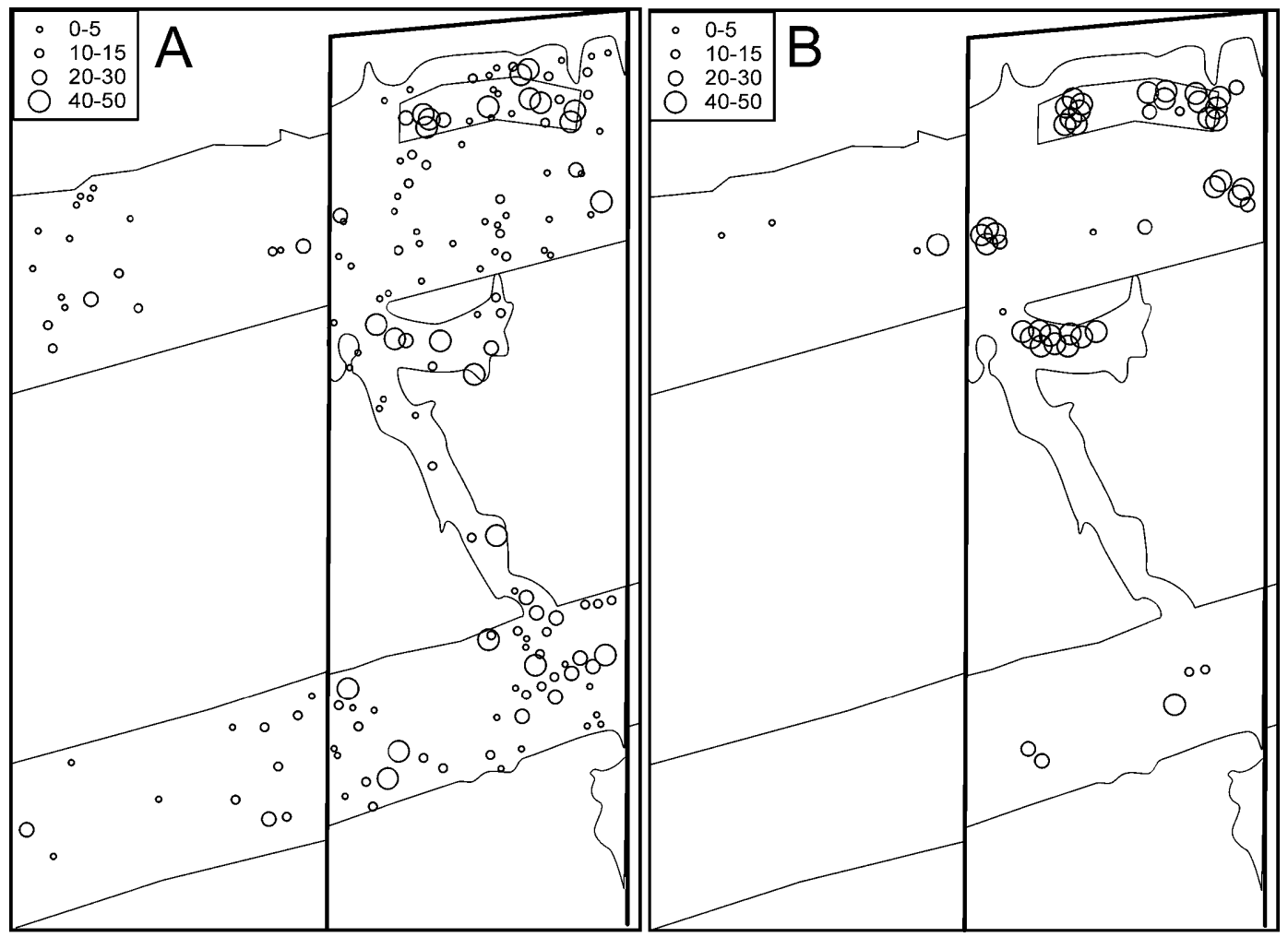

Fig. 3. The number and distribution of Succisa pratensis shoots based on a separate count in August 2004 (A) and of E. aurinia larvae during the time of the highest population density in April 2002 (B). 
TABLE 2. The mean and total numbers of Lepidoptera in the grazed and ungrazed meadow in 2001 to 2004. The annual means are based on the weekly values used in the statistical comparisons.

\begin{tabular}{|c|c|c|c|c|c|}
\hline & \multicolumn{2}{|c|}{ Grazed meadows } & \multicolumn{2}{|c|}{ Ungrazed controls } & \multirow{2}{*}{$P$} \\
\hline & mean & total & mean & total & \\
\hline Species richness & 47.3 & 71 & 45.3 & 67 & 0.102 \\
\hline Butterflies & 29.3 & 40 & 26.5 & 35 & $0.026^{*}$ \\
\hline Diurnal moths & 18.0 & 31 & 18.8 & 32 & 0.887 \\
\hline Total abundance & 444.5 & 1,778 & 381.0 & 1,524 & $0.006^{* *}$ \\
\hline Butterflies & 318.8 & 1,275 & 240.0 & 960 & $0.002 * *$ \\
\hline Diurnal moths & 125.8 & 503 & 141.0 & 564 & 0.083 \\
\hline
\end{tabular}

Significance (Wilcoxon paired samples test): $* * P<0.01, * P<$ 0.05

The results of the MRPP analysis indicated no difference in their species composition $(T=-0.52, P=0.291)$. Lepidoptera in both habitats were equally dominated by the butterfly species Aphantopus hyperantus, Brenthis ino, Thymelicus lineola, Boloria selene and the geometrid moth Scotopteryx chenopodiata, which accounted for $44 \%$ of all the individuals observed. Most of the species for which at least 10 individuals were observed, were recorded in higher numbers in the grazed meadows (Table 4).

According to the sample plots, the plant species diversity was significantly higher in the grazed meadows (57 in total, 19.6 on average) than in ungrazed controls (41 in total, 13.7 on average) (Mann-Whitney $U$ test, $P=$
0.008). A total of 11 species exhibited a significant difference between the two habitats (Table 3 ). The most typical species of the grazed meadows included Ranunculus acris and Lathyrus pratensis, whereas Epilobium angustifolium and Calamagrostis epigejos were most abundant in the ungrazed controls. Based on the sward heights given by Hämet-Ahti et al. (1998) of the species presented in Table 3 the average sward heights in the grazed meadows (53 $\mathrm{cm})$ was significantly lower than in the ungrazed controls $(86 \mathrm{~cm})(t$-test, $P=0.049)$.

The numbers of Succisa pratensis, recorded in three grazed plots (mean cover $3.3 \%$ ) and one ungrazed plot (mean cover $0.1 \%$ ), were not significantly different (Mann-Whitney $U$ test, $P=0.234$ ). In a separate count of Succisa shoots in August 2004, however, the numbers were six times higher in the grazed (1660 shoots) than in the ungrazed meadow (260 shoots). In addition, Succisa was frequently observed in the corridor between the two grazed meadows (Fig. 3).

A total of 72 plant species were recorded in the seven quadrats located in the northern grazed meadow. Between 1995 and 2004, the frequency of Succisa increased along with the total and average number of plant species (Table 5).

\section{DISCUSSION}

Grazing management is a commonly used method for restoring semi-natural habitats (Oates, 1995; WallisDeVries et al., 1998; Pöyry et al., 2005). The reintroduction of grazing has benefited some threatened butterflies

TABLE 3. Comparison of the most indicative plant species in the sample plots in the grazed $(n=10)$ and ungrazed meadow $(n=$ 10). Taxa are arranged in order of their preference for the grazed (upper) or ungrazed meadow (lower, separated by a dotted line). Another 43 plant species recorded in the plots are excluded from the table as none exhibited a statistically significant difference between the two habitats $(P>0.141$ for grazed and $P>0.317$ for ungrazed meadow).

\begin{tabular}{|c|c|c|c|c|c|}
\hline & \multicolumn{2}{|c|}{ Number of plots } & \multicolumn{2}{|c|}{ Mean cover $(\%)$} & \multirow{2}{*}{$P$} \\
\hline & Grazed & Ungrazed & Grazed & Ungrazed & \\
\hline Ranunculus acris & 9 & 3 & 4.6 & 0.6 & $0.003 * *$ \\
\hline Lathyrus pratensis & 10 & 4 & 5.9 & 0.8 & $0.007 * *$ \\
\hline Phleum pratense & 8 & 1 & 1.9 & 0.3 & $0.008 * *$ \\
\hline Trifolium repens & 5 & 0 & 1.7 & 0.0 & $0.013^{*}$ \\
\hline Deschampsia cespitosa & 10 & 5 & 32.1 & 9.8 & $0.014^{*}$ \\
\hline Viola canina & 6 & 1 & 0.3 & 0.0 & $0.018^{*}$ \\
\hline Rumex acetosella & 6 & 1 & 0.2 & 0.0 & $0.021 *$ \\
\hline Agrostis capillaris & 7 & 4 & 9.1 & 3.1 & 0.095 \\
\hline Achillea millefolium & 8 & 4 & 0.9 & 0.6 & 0.125 \\
\hline Filipendula ulmaria & 9 & 3 & 6.4 & 12.0 & 0.137 \\
\hline Rosa majalis & 2 & 5 & 0.4 & ${ }^{-} 0.7^{-}$ & $\overline{0} . \overline{2} 84$ \\
\hline Angelica sylvestris & 2 & 4 & 0.4 & 3.8 & 0.284 \\
\hline Geranium sylvaticum & 4 & 7 & 7.7 & 6.2 & 0.191 \\
\hline Dactylis glomerata & 0 & 2 & 0.0 & 0.3 & 0.147 \\
\hline Melampyrum sylvaticum & 0 & 2 & 0.0 & 0.3 & 0.147 \\
\hline Festuca rubra & 0 & 3 & 0.0 & 1.1 & 0.068 \\
\hline Anthriscus sylvestris & 3 & 8 & 1.2 & 6.2 & $0.039 *$ \\
\hline Cirsium helenioides & 1 & 6 & 0.1 & 14.5 & $0.013 *$ \\
\hline Calamagrostis epigejos & 5 & 9 & 1.7 & 14.4 & $0.006^{* *}$ \\
\hline Epilobium angustifolium & 1 & 8 & 0.1 & 10.0 & $0.002 * *$ \\
\hline
\end{tabular}

Significance (Mann Whitney $U$ test): ${ }^{* *} P<0.01, * P<0.05$ 
TABLE 4. Species of Lepidoptera (butterflies and diurnal moths) recorded in the transect counts. Species (42) are arranged in decreasing order of total abundance; those observed in lower numbers $(<10$ individuals $)$ are included in the group called "Others".

\begin{tabular}{|c|c|c|c|}
\hline & \multirow{2}{*}{$\begin{array}{c}\text { Total } \\
\text { abundance }\end{array}$} & \multicolumn{2}{|c|}{ Grazed meadows } \\
\hline & & abundance & percentage \\
\hline Aphantopus hyperantus & 576 & 313 & 54.3 \\
\hline Brenthis ino & 279 & 144 & 51.6 \\
\hline Scotopteryx chenopodiata & 240 & 121 & 50.4 \\
\hline Thymelicus lineola & 191 & 114 & 59.7 \\
\hline Boloria selene & 157 & 97 & 61.8 \\
\hline Lycaena virgaureae & 108 & 80 & 74.1 \\
\hline Euclidia glyphica & 108 & 60 & 55.6 \\
\hline Euphydryas aurinia & 94 & 69 & 73.4 \\
\hline Idaea serpentata & 89 & 55 & 61.8 \\
\hline Polypogon tentacularius & 84 & 32 & 38.1 \\
\hline Scopula immorata & 83 & 42 & 50.6 \\
\hline Chiasmia clathrata & 83 & 31 & 37.3 \\
\hline$\overline{\text { Aporia crataegi }}$ & 81 & 34 & 42.0 \\
\hline Coenonympha glycerion & 76 & 58 & 76.3 \\
\hline Ematurga atomaria & 76 & 32 & 42.1 \\
\hline Ochlodes sylvanus & 70 & 31 & 44.3 \\
\hline Aricia eumedon & 65 & 27 & 41.5 \\
\hline Pieris napi & 55 & 28 & 50.9 \\
\hline Cryptocala chardinyi & 54 & 11 & 20.4 \\
\hline Argynnis aglaja & 53 & 28 & 52.8 \\
\hline$\underline{\text { Siona lineata }}$ & 50 & 25 & 50.0 \\
\hline Polyommatus amandus & 48 & 37 & 77.1 \\
\hline Melitaea athalia & 42 & 31 & 73.8 \\
\hline Erebia ligea & 37 & 10 & 27.0 \\
\hline Odezia atrata & 36 & 12 & 33.3 \\
\hline$\overline{\text { Nymphalis io }}$ & 34 & 19 & 55.9 \\
\hline Argynnis paphia & 31 & 20 & 64.5 \\
\hline Nymphalis urticae & 30 & 13 & 43.3 \\
\hline Gonepteryx rhamni & 29 & 16 & 55.2 \\
\hline Rheumaptera hastata & 27 & 13 & 48.1 \\
\hline Xanthorhoe montanata & 27 & 11 & 40.7 \\
\hline Argynnis adippe & 25 & 21 & 84.0 \\
\hline Lasiommata maera & 23 & 8 & 34.8 \\
\hline Aricia artaxerxes & 21 & 13 & 61.9 \\
\hline Diacrisia $\underline{\text { sannio }}$ & 17 & 10 & 58.8 \\
\hline Pieris rapae & 17 & 3 & 17.6 \\
\hline Polyommatus icarus & 15 & 11 & 73.3 \\
\hline Lycaena hippothoe & 15 & 11 & 73.3 \\
\hline Leptidea sinapis & 13 & 6 & 46.2 \\
\hline Polyommatus semiargus & 12 & 9 & 75.0 \\
\hline Rivula sericealis & 12 & 6 & 50.0 \\
\hline Eilema $\underline{\text { lutarellum }}$ & 11 & 5 & 45.5 \\
\hline Others (40 species) & 108 & 61 & 56.5 \\
\hline
\end{tabular}

(e.g., Thomas, 1989, 1990), but recovery may take years (Weiss, 1999), as was the case with Euphydryas aurinia. Failed attempts due to unsuitable grazing intensity are also documented (Oates, 1995). The case studies show that successful restoration depends on a detailed study of the ecology and habitat requirements of the species and the ability to manage the habitat to provide these requirements (Pullin, 1996). Our results showed that grazing benefited not only E. aurinia and its larval host plant, but also the butterfly fauna and meadow flora in general.

The value of our results is decreased by shortcomings in the experimental design and data collection. It depends on a unique pair of meadows in the province inhabited by the endangered butterfly species, which prevented replication. On the other hand, we had little information on the populations of E. aurinia and Succisa pratensis prior to the restoration. During the study, the dispersal of Succisa was only studied on one grazed meadow and the vegetation was not monitored each year. Yet our findings were in line with expectations.

A concentration of Succisa in the grazed habitat was further enhanced by the resumed grazing. The species dispersed and increased among the other plants typical of pastures, such as Trifolium repens, Ajuga pyramidalis and Prunella vulgaris (Pykälä, 2001). Most new stands were observed in the corridor between the two meadows and the southern grazed meadow, but unfortunately the vegetation was not monitored, because Succisa was practically absent there at the time of the restoration. This dispersal was, however, recorded in the northern grazed meadow. The higher abundance of Succisa in the pasture was revealed by the separate count of shoots, although the comparison of sample plots indicated no difference between the meadows and controls.

Although Succisa shoots contain alkaloids (Hultin \& Torssell, 1964), which make the species unpalatable for cattle, the number of adult plants, the relative proportion of seedlings and seed-set have all been reported to correlate negatively with grazing intensity (Bühler \& Schmid, 2001). In fact, Succisa was extensively grazed in the summer of 1996, especially in the northern meadow. Consequently, the increased mortality of E. aurinia larvae was possibly a key factor in the decline of the species in subsequent years. By adjusting the grazing pressure, we succeeded in restoring the local population to a viable level. However, the low numbers in 2004 were again due to overgrazing the previous season. Approximately $94 \%$ of all larvae were inside the enclosure, while previously

TABLE 5. The results of the vegetation monitoring in seven quadrats in the northern grazed meadow between 1995 and 2004 . The meadow was ungrazed between 1997 and 1999.

\begin{tabular}{lcccccccccc}
\hline & 95 & 96 & 97 & 98 & 99 & 00 & 01 & 02 & 03 & 04 \\
\hline Grazing intensity $^{1}$ & - & 165 & - & - & - & 174 & 128 & 150 & 210 & 213 \\
Total number of species & 42 & 42 & 54 & 55 & 53 & 49 & 52 & 56 & 51 & 56 \\
Mean number of species & 16.3 & 18.1 & 23.4 & 23.9 & 24.0 & 21.4 & 23.3 & 23.4 & 23.3 & 27.3 \\
Mean cover (\%) & 108 & 93 & 109 & 107 & 111 & 82 & 102 & 101 & 102 & 115 \\
Number of Succisa quadrats & 1 & 1 & 1 & 2 & 2 & 2 & 3 & 3 & 5 & 5 \\
Mean cover (\%) of Succisa & 0.1 & 0.0 & 0.1 & 0.2 & 0.2 & 0.2 & 0.3 & 0.3 & 0.3 & 1.2 \\
\hline
\end{tabular}

\footnotetext{
${ }^{1}$ Grazing intensity $=$ the grazing period in days multiplied by the number of grazers.
} 
the proportion ranged from $46 \%$ to $82 \%$. These observations underscore the importance of a continuous monitoring of the effects on the target species in restoration and management projects aimed at conserving endangered species.

Unfortunately, time and labour intensive monitoring is likely to hinder the implementation of such protocols by landowners and governmental agencies. The possibility of overgrazing and the need for intensive surveys may have been decreased, for example, by altering the grazing regime in alternate years. In our case it was not possible because the landowner was bound by management stipulations based on the Finnish agri-environment support scheme. As similar cases are likely to occur elsewhere, more flexible legislation would undoubtedly facilitate the development of more suitable conservation management procedures. A decrease in the number of grazing animals, on the other hand, has increased the pressure to switch from grazing to mowing, which may be a useful and more cost effective way of managing butterfly habitats (Saarinen \& Jantunen, 2005).

After 14 years, the present population of E. aurinia at this site is undoubtedly one of the strongest in Finland. Over the same period, many local populations in clearcut areas surveyed by Klemetti (1998), have disappeared according to the authors' recent visits to these sites. The numbers of both larvae and adults of E. aurinia were considerably higher in the grazed than in the ungrazed meadow, in spite of their being situated so close to each other and well within the dispersal capability of the species (Wahlberg et al., 2002a). For this local metapopulation of E. aurinia, the abundance of Succisa was the most significant variable predicting the occurrence of the species in a habitat (Klemetti, 1998). It is likely that both the quantity and quality of the food resources determine the favourability of a grazed habitat. Konvička et al. (2003) reported that larval nests are associated with dense clumps of host plants of low to medium height and mechanical disturbance. In addition, nests were more often found in more acidic and less nitrogen-rich conditions, as in our study. Correspondingly, Anthes et al. (2003) reported that both host plant size and the structure of the vegetation surrounding host plants influence egg deposition by females. Here the location of larval nests confirmed that dense clumps of large Succisa shoots in open vegetation are of special interest to egg-laying females of E. aurinia.

Despite the abundance of the host plant in the southern grazed meadow, the low numbers of $E$. aurinia there indicate that individuals were reluctant to fly along the $125 \mathrm{~m}$ corridor between the two meadows. This accords with the outdoor cage experiment of Norberg et al. (2002), which indicated that E. aurinia is reluctant to fly in the shady parts of a habitat. The corridor was sunny for less than two hours per day, which apparently was sufficient for a few females to emigrate and lay their eggs in the southern meadow. According to field observations, individuals in the northern grazed meadow tended to emigrate more frequently to the open ungrazed habitat. In 2002, a female observed in the verge of the adjacent gravel road had moved approximately 250 metres along the open cultivated habitat under the same power line.

Web surveys are considered the most practical means of assessing the status of E. aurinia in a habitat (Lewis \& Hurford, 1997). Besides grazing, larvae were simultaneously affected by some unmeasured factors, such as weather and parasitoids. In 2003, the small number of larvae per web was due to the warm spring resulting in the rapid dispersal of larvae (Jantunen et al., 2003). The rate of parasitism of this species is weather-dependent (Porter, 1983), and the marked fluctuations in population size are mainly attributable to the activity of parasitoid wasps (Porter, 1981). In Joutseno, the larvae are attacked exclusively by the host-specific braconid Cotesia bignelii (Komonen, 1997). A temporary decline in E. aurinia abundance in the years 1997-1999 was considered to be a result of grazing pressure, since few individuals in local populations were parasitised in 1996 (Komonen, 1997). However, weather and parasitisation may partly explain the marked fluctuations in the numbers of larvae since 2000. In general, parasitoids and the lack of proper management of the habitat are often responsible for the extinction of local populations in E. aurinia metapopulations (Porter, 1981; Klemetti \& Wahlberg, 1997; Lewis \& Hurford, 1997).

The grazing also favoured other species of Lepidoptera as they became more abundant, yet the total species richness and species composition did not differ significantly between the two habitats. Meadow butterflies in particular, as classified by Pitkänen et al. (2001), were more abundant in the grazed (18 species, 1,037 individuals) than in ungrazed meadow (16 species, 704 individuals). The blue butterfly Aricia eumedon was the only species recorded in larger numbers in the ungrazed controls. Our observations confirm that extensive (forest) grazing can be used to enhance butterfly diversity in restoration projects (WallisDeVries \& Raemakers, 2001). Unfortunately forest grazing is currently rarely practised in Finland. Most livestock systems are characterised by rather small, enclosed pastures under high overall grazing pressure, which is harmful to many butterflies (e.g., Dolek \& Geyer, 1997; Elligsen et al., 1997; Kruess \& Tscharntke, 2002).

Diurnal moths, on the other hand, were adversely affected by grazing. The transect data indicates there are many species (e.g. Diacrisia sannio, Scotopteryx chenopodiata) that only fly when disturbed during the daytime. Hence the availability of shelter in the form of the taller vegetation, characteristic of the ungrazed controls, probably accounts for the higher numbers of moths in the ungrazed meadow. Similarly Jantunen et al. (2004) record that tall vegetation is important for diurnal moth communities living in roadside verges.

The higher number of plant species in the grazed meadow verified the expectation of a higher diversity of meadow flora in the pasture. Pykälä (2003) also reports that cattle grazing increased plant species richness, based on a comparison of grazed and abandoned grasslands in 
SW Finland. In our study, the number of species in the meadow quadrats increased from 42 to 56 over the ten years. The grazing provided more space for several small grassland species, such as Prunella vulgaris, Cerastium fontanum and Ajuga pyramidalis. The grazed habitat was typically preferred by species with rosettes (Pilosella cymosa, Taraxacum spp.), rough leaves (Deschampsia cespitosa) and alkaloid-containing shoots (Ranunculus acris, $R$. auricomus, Veronica officinalis). In addition to selective defoliation, the grazing by cattle leads to lower concentrations of nutrients in the soil (Kooijman \& Smit, 2001), which are likely eventually to benefit both the grassland flora and fauna (e.g., Huntly, 1991; Weiss, 1999; Di Giulio et al., 2001).

We may conclude that the reintroduction of forest grazing improved the status of the threatened Euphydryas aurinia butterfly and its larval host plant at the restoration site. The conservation implications are that the species of interest require constant monitoring so that grazing intensity can be adjusted and that extensive grazing also benefits the meadow flora, which improves the habitat characteristics for a more diverse butterfly fauna.

ACKNOWLEDGEMENTS. The authors thank A. Hietala, P. Marttila, U. Tarvainen, O. Tervo and N. Wahlberg for assistance in the field. We are indebted to L. Plester, K. Mikkola and three anonymous referees for constructive comments on the manuscript. Financial support from the Raija ja Ossi Tuuliainen Foundation is gratefully acknowledged.

\section{REFERENCES}

Adams A.W. 1955: Succisa pratensis Moench. J. Ecol. 43: 709-718.

Anthes N., Fartmann T., Hermann G. \& Kaule G. 2003: Combining larval habitat quality and metapopulation structure the key for successful management of pre-alpine Euphydryas aurinia colonies. J. Insect Cons. 7: 175-185.

Barnett L.K. \& Warren M.S. 1995: Species Action Plan. Marsh Fritillary Eurodryas aurinia. Butterfly Conservation, Wareham, Dorset, 29 pp.

BÜHLER C. \& SCHMiD B. 2001: The influence of management regime and altitude on the population structure of Succisa pratensis: implications for vegetation monitoring. J. Appl. Ecol. 38: 689-698.

Di Giulio M., Edwards P.J. \& Meister E. 2001: Enhancing insect diversity in agricultural grasslands: the roles of management and landscape structure. J. Appl. Ecol. 38: 310-319.

Dolek M. \& Geyer A. 1997: Influence of management on butterflies of rare grassland ecosystems in Germany. J. Insect Cons. 1: 125-130.

Elligsen H., Beinlich B. \& Plachter H. 1997: Effects of largescale cattle grazing on populations of Coenonympha glycerion and Lasiommata megera (Lepidoptera: Satyridae). J. Insect Cons. 1: 13-23.

Hämet-Ahti L., Suominen J., Ulvinen T. \& Uotila P. 1998: Field Flora of Finland. 4th ed. Finnish Museum of Natural History, Botanical Museum, Helsinki, 656 pp. (in Finnish).

Huldén L. (ed.), Albrecht A., Itämies J., Malinen P. \& WetTENHOVI J. 2000: Atlas of Finnish Macrolepidoptera. Lepidopterological Society of Finland, Finnish Museum of Natural History, Helsinki, 328 pp. (in Finnish).

Hultin E. \& Torssell K. 1964: Alkaloid-screening of Swedish plants. Phytochemistry 4: 425-433.
Huntly N. 1991: Herbivores and the dynamics of communities and ecosystems. Annu. Rev. Ecol. Syst. 22: 477-503.

Jantunen J., Saarinen K. \& Valtonen A. 2003: Annual Report of the Restoration and Management in the Conservation Sites. South Karelia Allergy and Environment Institute, Joutseno, 30 pp. (in Finnish).

Jantunen J., SaArinen K., Valtonen A., Hugg T. \& SaArnio S. 2004: Vegetation and Lepidoptera Fauna in Roadside Habitats. Finnra Reports 9/2004. Finnish Road Administration, Helsinki, 57 pp. (in Finnish).

Klemetti T. 1998: The Metapopulation Structure of Marsh Fritillary (Eurodryas aurinia). M.Sc. Thesis, Department of Ecology and Systematics, University of Helsinki, 50 pp. (in Finnish.)

Klemetti T. \& Wahlberg N. 1997: The ecology and population structure of the marsh fritillary (Euphydryas aurinia) in Finland. Baptria 22: 87-93 (in Finnish).

Komonen A. 1997: The parasitoid complexes attacking Finnish populations of two threatened butterflies, Euphydryas maturna and E. aurinia. Baptria 22: 105-109 (in Finnish).

KonviČKA M., Hula V. \& FriC Z. 2003: Habitat of prehibernating larvae of the endangered butterfly Euphydryas aurinia (Lepidoptera, Nymphalidae): What can be learned from vegetation composition and architecture? Eur. J. Entomol. 100: 313-322.

Kooljman A.M. \& SMit A. 2001: Grazing as a measure to reduce nutrient availability and plant productivity in acid dune grasslands and pine forests in the Netherlands. Ecol. Eng. 17: 63-77.

Kruess A. \& Tscharntke T. 2002: Grazing intensity and the diversity of grasshoppers, butterflies, and trap-nesting bees and wasps. Cons. Biol. 16: 1570-1580.

LAVERY T.A. 1993: A review of the distribution, ecology and status of the marsh fritillary Euphydryas aurinia Rottemburg, 1775 (Lepidoptera, Nymphalidae) in Ireland. Ir. Nat. J. 24: 192-199.

Lewis O.T. \& Hurford C. 1997: Assessing the status of the marsh fritillary butterfly (Eurodryas aurinia): an example from Glamorgan, UK. J. Insect Cons. 1: 159-166.

Munguira M.L., Martin J., Garcia-Barros E. \& Viejo J.L. 1997: Use of space and resources in a Mediterranean population of the butterfly Euphydryas aurinia. Acta Oecol. 18: 597-612.

Norberg U., EnFJÄll K. \& Leimar O. 2002: Habitat exploration in butterflies - an outdoor cage experiment. Evol. Ecol. 16: $1-14$.

OAtes M.R. 1995: Butterfly conservation within the management of grassland habitats. In Pullin A.S. (ed.): Ecology and Conservation of Butterflies. Chapman \& Hall, London, pp. 98-112.

Pitkänen M., Kuussaari M. \& Pöyry J. 2001: Butterflies. In Pitkänen M. \& Tiainen J. (eds): Biodiversity of Agricultural Landscapes in Finland. Birdlife Finland Conservation Series (No. 3), Helsinki, pp. 51-68.

Pollard E. \& YATES T.J. 1993: Monitoring Butterflies for Ecology and Conservation. The British Butterfly Monitoring Scheme. Chapman \& Hall, London, 274 pp.

Porter K. 1981: The Population Dynamics of Small Populations of the Butterfly Euphydryas aurinia. Ph.D. Thesis, University of Oxford.

Porter K. 1983: Multivoltinism in Apanteles bignellii and the influence of weather on synchronisation with its host Euphydryas aurinia. Entomol. Exp. Appl. 34: 155-162.

Pöyry J., Lindgren S., Salminen J. \& KuUsSaAri M. 2005 : Responses of butterfly and moth species to restored cattle 
grazing in semi-natural grasslands. Biol. Conserv. 122 465-478.

Pullin A.S. 1996: Restoration of butterfly populations in Britain. Res. Ecol. 4: 71-80.

PYКÄLÄ J. 2001: Maintaining Biodiversity Through Traditional Animal Husbandry. The Finnish Environment 495. Finnish Environment Institute, Helsinki, 205 pp. (in Finnish).

PYKÄLÄ J. 2003: Effects of restoration with cattle grazing on plant species composition and richness of semi-natural grasslands. Biod. Conserv. 12: 2211-2226.

Rassi P., Alanen A., Kanerva T. \& Mannerkoski I. (eds) 2001 The 2000 Red List of Finnish Species. Ministry of the Environment, Helsinki, 432 pp. (in Finnish).

SAARINEN K. \& JANTUNEN J. 2005: Grassland butterfly fauna under traditional animal husbandry: contrasts in diversity in mown meadows and grazed pastures. Biod. Conserv. (in press).

SIEGEL S. 1956: Nonparametric Statistics for the Behavioral Sciences. McGraw-Hill Kogakusha, Tokyo, 312 pp.

Thомаs J.A. 1989: Ecological lessons from the reintroduction of Lepidoptera. Entomologist 108: 56-68.

Thomas J.A. 1990: The conservation of the Adonis blue and Lulworth skipper butterflies: two sides of the same coin. In Calcareous Grassland: Ecology and Management. British Ecological Society Symposium, Bluntisham Books, Bluntisham, pp. 112-117.

van SwaAy C.A.M. \& Warren M.S. 1999: Red Data Book of European Butterflies (Rhopalocera). Nature and
Environment, No. 99. Council of Europe Publishing, Strasbourg, $260 \mathrm{pp}$.

WahlBerg N. 2000: Comparative descriptions of the immature stages and ecology of the Finnish melitaeine butterfly species (Lepidoptera: Nymphalidae). Entomol. Fenn. 11: 167-174.

Wahlberg N., Klemetti T., Selonen V. \& Hanski I. 2002a: Metapopulation structure and movements in five species of checkerspot butterflies. Oecologia 130: 33-43.

Wahlberg N., Klemetti T. \& Hanski I. 2002b: Dynamic populations in a dynamic landscape: the metapopulation structure of the marsh fritillary butterfly. Ecography 25: 224-232.

WallisDeVries M.F. \& Raemakers I. 2001: Does extensive grazing benefit butterflies in coastal dunes? Res. Ecol. 9: 179-188.

WallisDeVries M.F., BaKKer J.P. \& VAN Wieren S.E. (eds) 1998: Grazing and Conservation Management. Kluwer Academic Publishers, Dordrecht, 374 pp.

WARREN M.S. 1994: The UK status and suspected metapopulation structure of a threatened European butterfly, the Marsh Fritillary, Eurodryas aurinia. Biol. Conserv. 67: 239-249.

WeIss S.B. 1999: Cars, cows, and checkerspot butterflies: nitrogen deposition and management of nutrient-poor grasslands for a threatened species. Cons. Biol. 13: 1476-1486.

Zimmerman G.M., Goetz H. \& Mielke Jr. P.W. 1985: Use of an improved statistical method for group comparisons to study effects of prairie fire. Ecology 66: 606-611.

Received January 28, 2005; revised March 31, 2005; accepted June 9, 2005 